\title{
Annual Report on the External Quality Assessment Scheme for General Chemistry in Korea (2017)
}

\author{
Yong-Wha Lee \\ Department of Laboratory \\ Medicine \& Genetics, \\ Soonchunhyang University \\ Bucheon Hospital, \\ Soonchunhyang University \\ College of Medicine, \\ Bucheon, Korea
}

In 2017, the clinical chemistry proficiency testing program consisted of 24 programs with the addition of the urine chemistry program in the Korean Association of External Quality Assessment Service. The routine chemistry program consisted of 32 test items, including osmolality, total $\mathrm{CO}_{2}$, and estimated glomerular filtration rate tests, and the urine chemistry program consisted of 12 test items, including the albumin test. Based on the information and results of each test item entered by each institution, statistical analysis data according to test method, instrument, and reagent were reported. The statistics included the number of participating institutions, mean, standard deviation, coefficient of variation, median, minimum, and maximum values for each group. Each report was composed of a table, histogram, Levy-Jennings chart, and standard deviation index showing statistics by each test item. A total of 14 items, including albumin, were evaluated by more than 1,000 institutions, and the number of participating institutions is continuously increasing. The coefficient of variation tended to increase, as the concentration of the control material was lower for each test item. Most of them showed a coefficient of variation within $10 \%$. Alkaline phosphatase and lactate dehydrogenase were found to have high coefficients of variation due to differences in measurement values between measurement methods. The distribution of measurement methods in general chemistry test items was not significantly different from that of previous years, and the distribution of measurement methods for albumin, glucose, phosphorus, and protein among the urine chemistry program was different from that of the routine chemistry program.

(J Lab Med Qual Assur 2018;40:113-127)

Key Words: Proficiency testing, Clinical chemistry, Korean Association of External Quality Assessment Service
서론

대한임상검사정도관리협회에서는 2016년부터 새로운 운영 방식의 차세대 신빙도조사사업을 시행하고 있다. 가장 큰 변화 는 6 개 대분류하에 46 개 프로그램 단위별 운영체계로 전환하 여 검사항목을 확대한 점이 되겠다[1-3]. 2017년도에는 임상 화학 분야에는 3 개의 프로그램이 추가되어 일반화학검사 프로 그램을 비롯하여 총 24 개의 프로그램으로 구성되었다. 일반화 학검사 프로그램에는 삼투압(osmolality)검사와 총 이산화탄 소(total $\mathrm{CO}_{2}$ )검사가 추가되었고 3회차부터 성인과 소아의 추 정 사구체여과율검사가 시범사업으로 추가되어 총 32 개의 검 사항목으로 확대되었다. 또한 일반화학검사 프로그램 외에 요
화학검사 프로그램이 신설되어 알부민검사 등 총 12 개의 검사 항목에 대한 신빙도조사가 2 회에 걸쳐 시행되었다.

저자들은 2017년 대한임상검사정도관리협회의 신빙도조사 사업으로 실시되었던 일반화학검사와 요화학검사에 대한 신 빙도조사사업 결과를 분석하여 보고하고자 한다.

\section{재료 및 방법}

\author{
1. 대상 \\ 일반화학검사 프로그램은 연 4회에 걸쳐, 회차별로 3 개의 \\ 정도관리물질이 이용되어 시행되었다. 물질은 냉장상태가 유 \\ 지될 수 있도록 아이스팩이 내장된 특수 제작박스에 넣어 참여
}




\section{Journal of LABORATORY MEDICINE and QUALITY ASSURANCE}

\section{Yong-Wha Lee • External Quality Assessment for General Chemistry}

등록기관을 대상으로 1 회차와 2회차는 3월 27일에 발송되었 고 3회차와 4회차는 10 월 16 일에 발송되었다. 요화학검사 프 로그램은 연 2 회에 걸쳐 회차별로 3 개의 정도관리물질이 이용 되었고 1 회차와 2 회차를 각각 6 월 13 일과 9 월 18 일에 발송하 였다.

\section{2. 정도관리물질과 검사항목}

일반화학검사의 정도관리물질은 사람 혈청을 기질로 한 분 말제품인 Randox사(London, UK)와 Bio-Rad사(Bio-Rad Laboratories, Hercules, CA, USA)의 사람 혈청을 기질로 한 분말제품을 사용하였다(Table 1). 검사항목은 1회차와 2 회차는 총 30 항목이었고 3 회차와 4회차는 성인과 소아의 추 정 사구체여과율 항목이 추가되어 총 32항목이었다. 요화학검 사의 정도관리물질은 Bio-Rad사의 Lyphochek Quantitative Urine Control을 사용하였다. 검사항목은 알부민 등 총 12 항 목이었다(Table 2). 사전에 공지된 일정에 따라 물질을 수령
한 참여기관에서는 검사 시행 후 지정된 회신 마감일 이내에 대한임상검사정도관리협회 신빙도조사사업 홈페이지(http:// eqas.keqas.org)에 결과를 입력하도록 하였다. 기기회사와 시 약회사로부터 제공된 검사항목별 검사방법, 기기와 시약에 대 해 기초자료를 검토한 바를 토대로 참여기관이 홈페이지상에 서 해당 검사항목에 대한 검사정보 선택과 결과 입력이 가능하 도록 전산체계를 구축하였다.

\section{3. 결과 판정 및 분석}

일반화학검사와 요화학검사 각각에 대해서 각 기관에서 입 력한 각 검사항목에 대한 정보와 결과를 기반으로 검사방법, 기기, 시약에 따라 통계분석을 시행하였고 이를 전체 참여기관 의 특성을 보여주는 공통보고서와 개별기관의 평가자료를 보 여주는 기관별 보고서로 나누어 보고하였다. 공통보고서는 3 단계로 그룹화하여 통계치를 제시하였다. 전체 참여기관에 해 당하는 통계, 검사방법을 기준분류로 한 그룹의 통계와 검사방

Table 1. Control materials provided for analysis and released dates from the routine chemistry trials in 2017

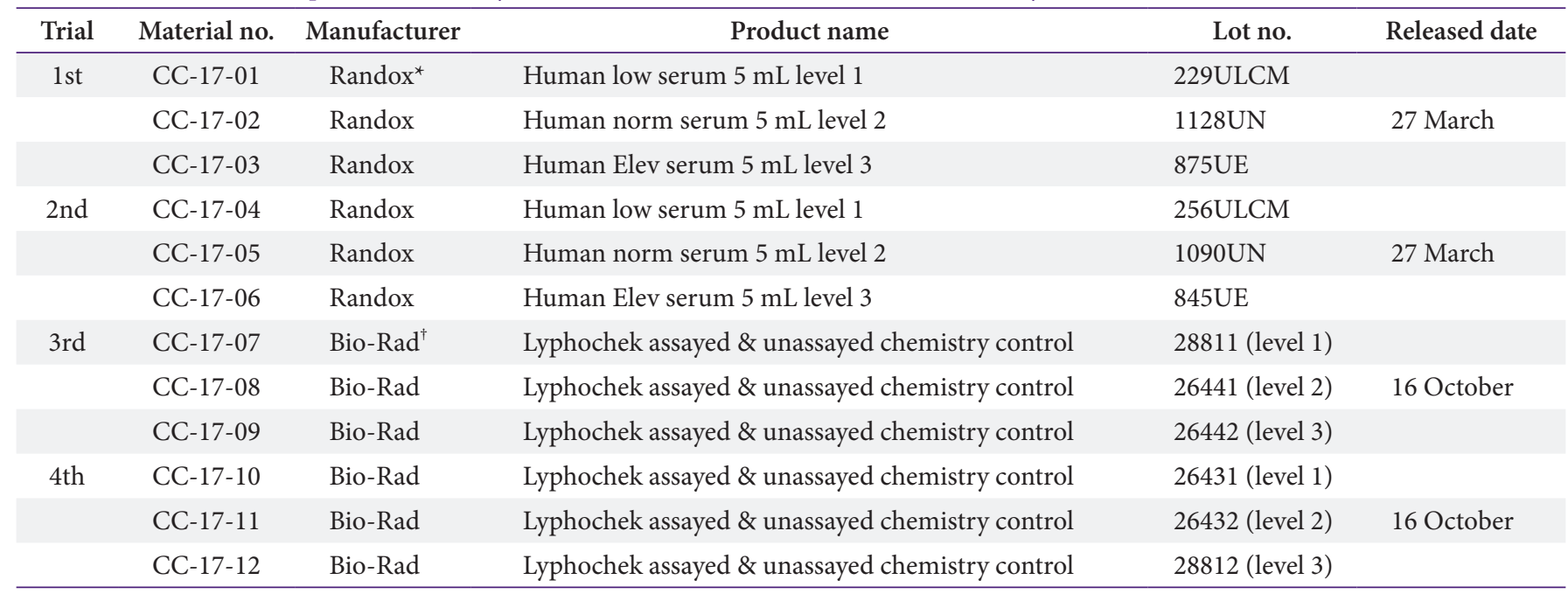

${ }^{*}$ Randox Laboratories (London, UK), ${ }^{\dagger}$ Bio-Rad Laboratories (Hercules, CA, USA).

Table 2. Control materials provided for analysis and released dates from the urine chemistry trials in 2017

\begin{tabular}{|c|c|c|c|c|c|}
\hline Trial & Material no. & Manufacturer & Product name & Lot no. & Released date \\
\hline \multirow[t]{3}{*}{1 st } & CUC-17-01 & Bio-Rad ${ }^{*}$ & Lyphochek quantitative urine control & 63371 (level 1) & \\
\hline & CUC-17-02 & Bio-Rad & Lyphochek quantitative urine control & 63381 (level 1) & 13 June \\
\hline & CUC-17-03 & Bio-Rad & Lyphochek quantitative urine control & 63382 (level 2) & \\
\hline \multirow[t]{3}{*}{ 2nd } & CUC-17-04 & Bio-Rad & Lyphochek quantitative urine control & 63391 (level 1) & \\
\hline & CUC-17-05 & Bio-Rad & Lyphochek quantitative urine control & 63392 (level 2) & 18 September \\
\hline & CUC-17-06 & Bio-Rad & Lyphochek quantitative urine control & 63372 (level 2) & \\
\hline
\end{tabular}

${ }^{\star}$ Bio-Rad Laboratories (Hercules, CA, USA). 


\section{Journal of LABORATORY MEDICINE and QUALITY ASSURANCE}

Yong-Wha Lee • External Quality Assessment for General Chemistry

법별로 시약회사를 세분류한 그룹의 통계를 각각 제시하였다.

제시된 통계에는 각 그룹별 참여기관 수, 평균, 표준편차, 변동계수, 중앙값, 최소값과 최대값이 포함되도록 하였고 참 여기관 수, 중앙값, 최소값과 최대값은 이상치를 제거하지 않 은 수치를 제시하였고 평균, 표준편차와 변동계수는 각 그룹 별로 이상치를 제거한 후 산출된 수치를 사용하였다. 또한 해 당 분류에 속한 기관 수가 10 개 미만인 경우 평균, 표준편차와
변동계수를 제시하지 않았고 기관 수가 3개 미만인 경우 중앙 값도 제시하지 않았다. 이상치는 각 해당 분류에서 75 퍼센타 일 값(Q3)과 25퍼센타일 값(Q1)의 차(Q3-Q1, interquartile range $[\mathrm{IQR}])$ 의 1.5 배를 초과하여 $\mathrm{Q} 1$ 보다 낮거나 Q3보다 높 은 결과값 $(<\mathrm{Q} 1-1.5 \times \mathrm{IQR}$ 또는 $>\mathrm{Q} 3+1.5 \times \mathrm{IQR})$ 으로 설정 하였다.

개별보고서는 각 검사항목별로 통계치를 보여주는 표, 히

Table 3. Number of laboratories that participated in each routine chemistry test in 2017

\begin{tabular}{|c|c|c|c|c|}
\hline \multirow{2}{*}{ Test } & \multicolumn{4}{|c|}{ Trial } \\
\hline & 1st & 2nd & 3 rd & 4 th \\
\hline Alanine transaminase & 1,416 & 1,420 & 1,585 & 1,569 \\
\hline Albumin & 1,302 & 1,305 & 1,463 & 1,447 \\
\hline Alkaline phosphatase & 1,241 & 1,244 & 1,401 & 1,389 \\
\hline Amylase & 733 & 733 & 798 & 788 \\
\hline Aspartate aminotransferase & 1,415 & 1,419 & 1,584 & 1,568 \\
\hline Bilirubin, direct & 728 & 725 & 783 & 774 \\
\hline Bilirubin, total & 1,305 & 1,308 & 1,468 & 1,452 \\
\hline Calcium & 662 & 664 & 712 & 702 \\
\hline Chloride & 876 & 878 & 986 & 977 \\
\hline Cholesterol, total & 1,407 & 1,411 & 1,572 & 1,557 \\
\hline Creatine kinase & 622 & 614 & 654 & 652 \\
\hline Creatinine & 1,356 & 1,358 & 1,524 & 1,514 \\
\hline Gamma-glutamyl transferase & 1,385 & 1,388 & 1,540 & 1,525 \\
\hline Glucose & 1,400 & 1,403 & 1,561 & 1,544 \\
\hline High density lipoprotein cholesterol & 1,308 & 1,309 & 1,447 & 1,432 \\
\hline Iron & 388 & 393 & 408 & 406 \\
\hline Lactate dehydrogenase & 831 & 824 & 886 & 878 \\
\hline Lipase & 394 & 392 & 406 & 400 \\
\hline Low density lipoprotein cholesterol & 834 & 829 & 903 & 890 \\
\hline Magnesium & 269 & 273 & 284 & 283 \\
\hline Osmolality & 129 & 135 & 143 & 143 \\
\hline Phosphorus & 617 & 617 & 664 & 658 \\
\hline Potassium & 888 & 891 & 999 & 990 \\
\hline Protein, total & 1,284 & 1,290 & 1,447 & 1,429 \\
\hline Sodium & 888 & 890 & 999 & 990 \\
\hline Total $\mathrm{CO}_{2}$ & 177 & 185 & 199 & 199 \\
\hline Total iron-binding capacity & 350 & 356 & 371 & 369 \\
\hline Triglyceride & 1,379 & 1,381 & 1,531 & 1,516 \\
\hline Urea nitrogen & 1,351 & 1,350 & 1,512 & 1,498 \\
\hline Uric acid & 1,103 & 1,098 & 1,201 & 1,191 \\
\hline Estimated glomerular filtration rate (adult) & & & 280 & 270 \\
\hline Estimated glomerular filtration rate (child) & & & 181 & 166 \\
\hline
\end{tabular}




\section{Journal of LABORATORY MEDICINE and QUALITY ASSURANCE}

\section{Yong-Wha Lee • External Quality Assessment for General Chemistry}

스토그램과 레비-제닝스 차트로 구성되도록 하였다. 통계치 를 제시한 표에는 각 기관의 결과값과 각 분류별 통계치를 제 시하고 기준분류와 세분류에서는 표준편차지수(standard deviation index, $\mathrm{SDI}$ )를 함께 제시하였다. 전체 결과에 대해 서는 $\mathrm{SDI}$ 를 제시하지 않았고 각 그룹에서 참가기관의 수가 10 개 미만일 경우 SDI를 제시하지 않았다.

히스토그램에서는 전체기관의 분포와 기준분류별 분포를 제 시하였고 각 기관의 위치를 표시하였다. 히스토그램은 20 개의 막대로 구성하였고 첫 번째와 마지막 막대는 각각 전체 참여기

Table 4. Number of laboratories that participated in each urine chemistry test in 2017

\begin{tabular}{lrc}
\hline \multirow{1}{*}{ Test } & \multicolumn{2}{c}{ Trial } \\
\cline { 2 - 3 } & 1st & 2nd \\
\hline Albumin & 123 & 135 \\
Calcium & 117 & 131 \\
Chloride & 131 & 148 \\
Creatinine & 142 & 161 \\
Glucose & 112 & 123 \\
Magnesium & 97 & 101 \\
Phosphorus & 114 & 122 \\
Potassium & 132 & 149 \\
Protein & 129 & 144 \\
Sodium & 132 & 150 \\
Urea nitrogen & 123 & 136 \\
Uric acid & 116 & 127 \\
\hline
\end{tabular}

관의 결과분포에서 2.5 퍼센타일 미만과 97.5 퍼센타일 이상에 해당하며 중간 막대들은 2.5 퍼센타일 값과 97.5 퍼센타일 값의 범위를 동일한 간격으로 나누어 분포를 나타내었다. 레비-제 닝스 차트는 기준분류별 $\mathrm{SDI}$ 를 이용하여 작성하였다.

\section{결과 및 고찰}

2017년에는 4회에 걸쳐 시행된 일반화학검사 프로그램과 2 회에 걸쳐 시행된 요화학검사 프로그램의 외부정도관리 분석 결과가 회차마다 추가 가입 여부에 따라 참여기관 수와 회신율 이 달랐기에 각 프로그램별로 매 회차마다 회신된 기관을 대상 으로 통계분석이 되었다. 정도관리물질은 회차마다 각각 서로 다른 로트번호를 갖는 물질을 이용하였고 회차별로 높은 농도 와 낮은 농도가 다양한 순서로 섞이도록 하였다.

일반화학검사 프로그램에서는 1,000 개 이상의 기관이 참 여하는 검사항목은 알부민, 알칼리인산분해효소(alkaline phosphatase, ALP), 알라닌아미노전이효소(alanine aminotransferase, ALT), 아스파르테이트아미노전이효소(aspartate aminotransferase, AST), 혈액요소질소(blood urea nitrogen, $\mathrm{BUN})$, 총 콜레스테롤, 크레아티닌, 감마글루타밀전이효소 (gamma-glutamyl transferase), 포도당, 고밀도지단백콜레 스테롤(high-density lipoprotein cholesterol, HDL-C), 총 단 백, 총 빌리루빈, 중성지방과 요산(uric acid) 등이었고 1회차 와 2 회차에 비해 3 회차와 4 회차의 참가기관 수가 증가하였다 (Table 3).

요화학검사 프로그램에서는 크레아티닌검사에 참여하는 기

Table 6. Peer-group coefficients of variation (\%) according to the test and trials of urine chemistry in 2017

\begin{tabular}{|c|c|c|c|c|c|c|}
\hline \multirow{2}{*}{ Test } & \multicolumn{6}{|c|}{ Trials } \\
\hline & CUC-17-01 & CUC-17-02 & CUC-17-03 & CUC-17-04 & CUC-17-05 & CUC-17-06 \\
\hline Albumin & 36.1 & 38.0 & 23.6 & 49.6 & 22.9 & 23.3 \\
\hline Calcium & 3.6 & 3.1 & 3.0 & 3.5 & 2.5 & 2.4 \\
\hline Chloride & 8.1 & 9.3 & 3.1 & 8.6 & 2.7 & 2.8 \\
\hline Creatinine & 5.3 & 5.7 & 5.5 & 4.8 & 4.5 & 4.7 \\
\hline Glucose & 3.3 & 3.4 & 2.4 & 3.7 & 2.4 & 2.7 \\
\hline Magnesium & 3.5 & 4.5 & 6.3 & 3.4 & 4.1 & 4.9 \\
\hline Phosphorus & 3.0 & 3.1 & 3.3 & 2.8 & 2.7 & 2.9 \\
\hline Potassium & 2.2 & 2.5 & 4.0 & 2.4 & 4.0 & 4.3 \\
\hline Protein & 14.3 & 14.6 & 9.4 & 13.5 & 8.8 & 9.6 \\
\hline Sodium & 2.5 & 2.5 & 1.2 & 2.4 & 1.2 & 1.2 \\
\hline Urea nitrogen & 3.8 & 3.7 & 3.3 & 3.5 & 3.4 & 3.0 \\
\hline Uric acid & 4.8 & 5.6 & 4.3 & 4.6 & 3.7 & 3.6 \\
\hline
\end{tabular}




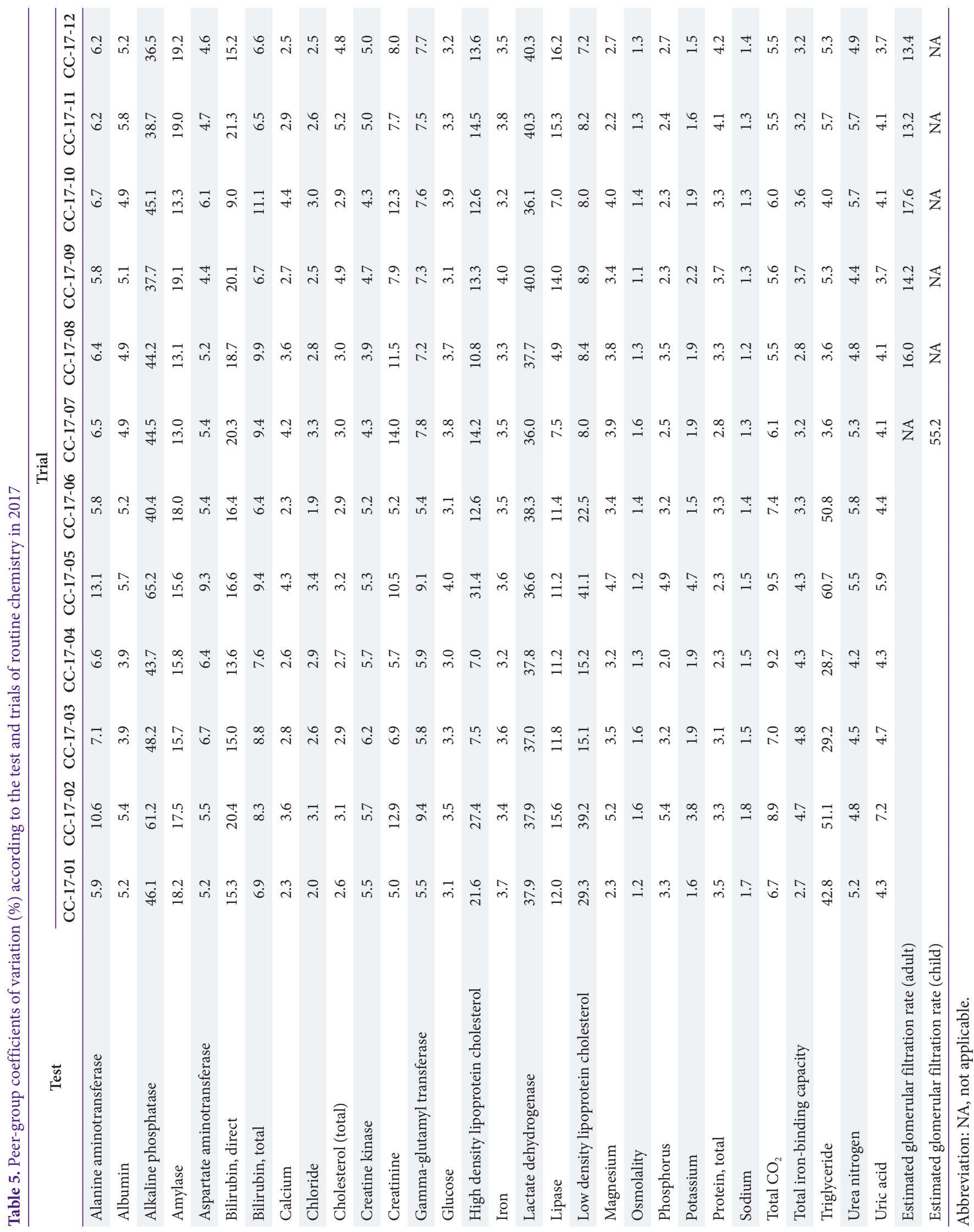




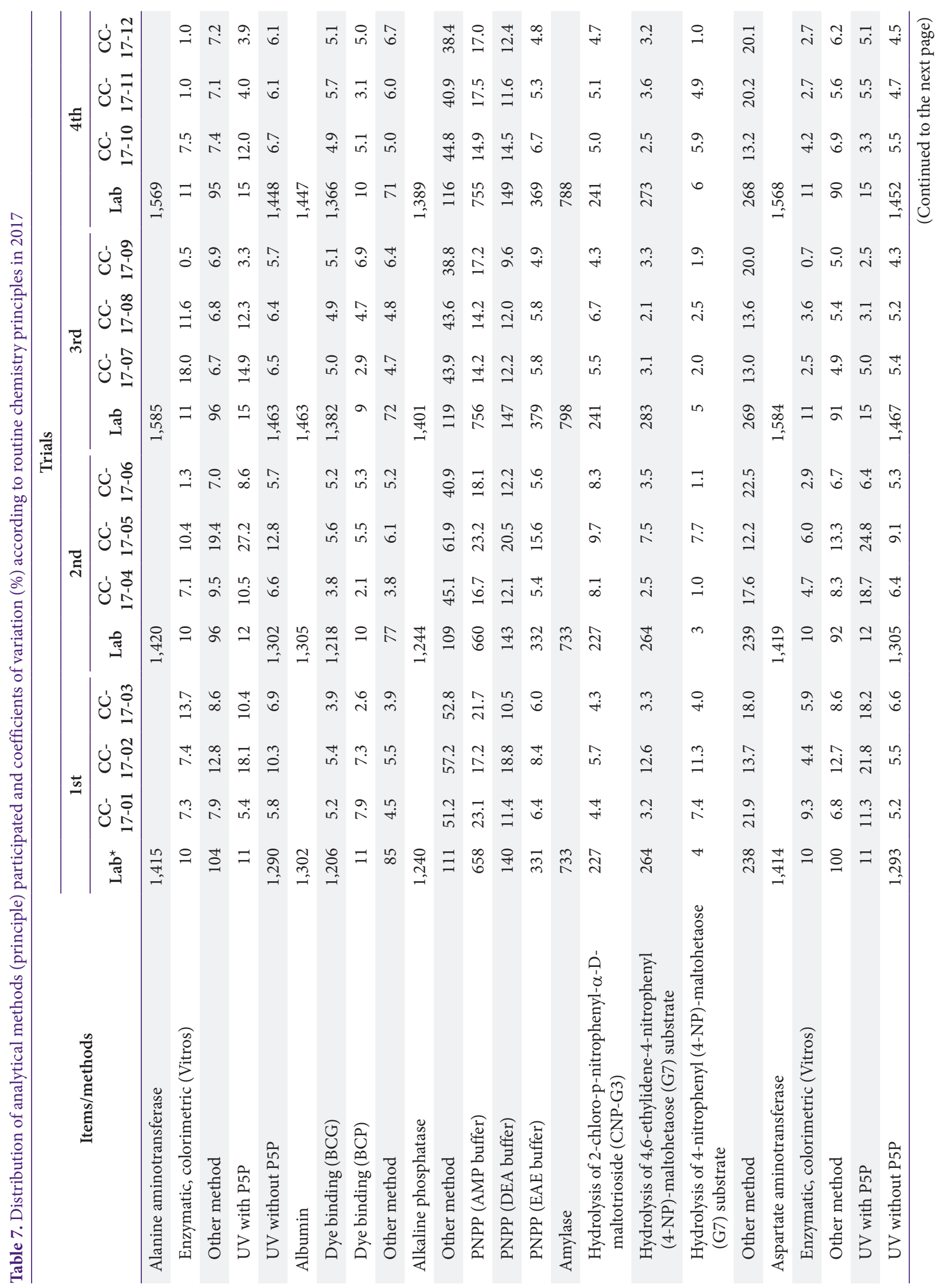




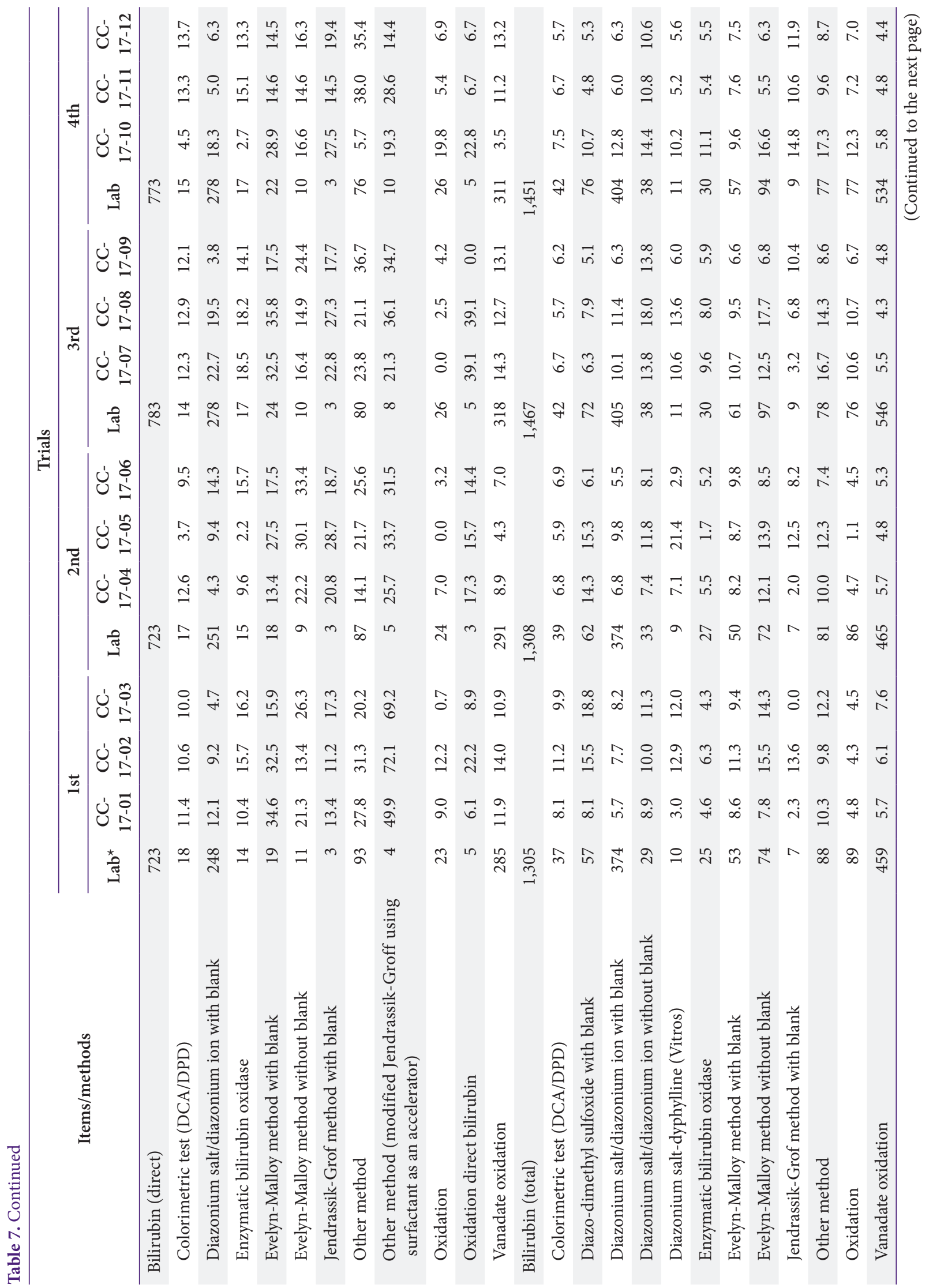




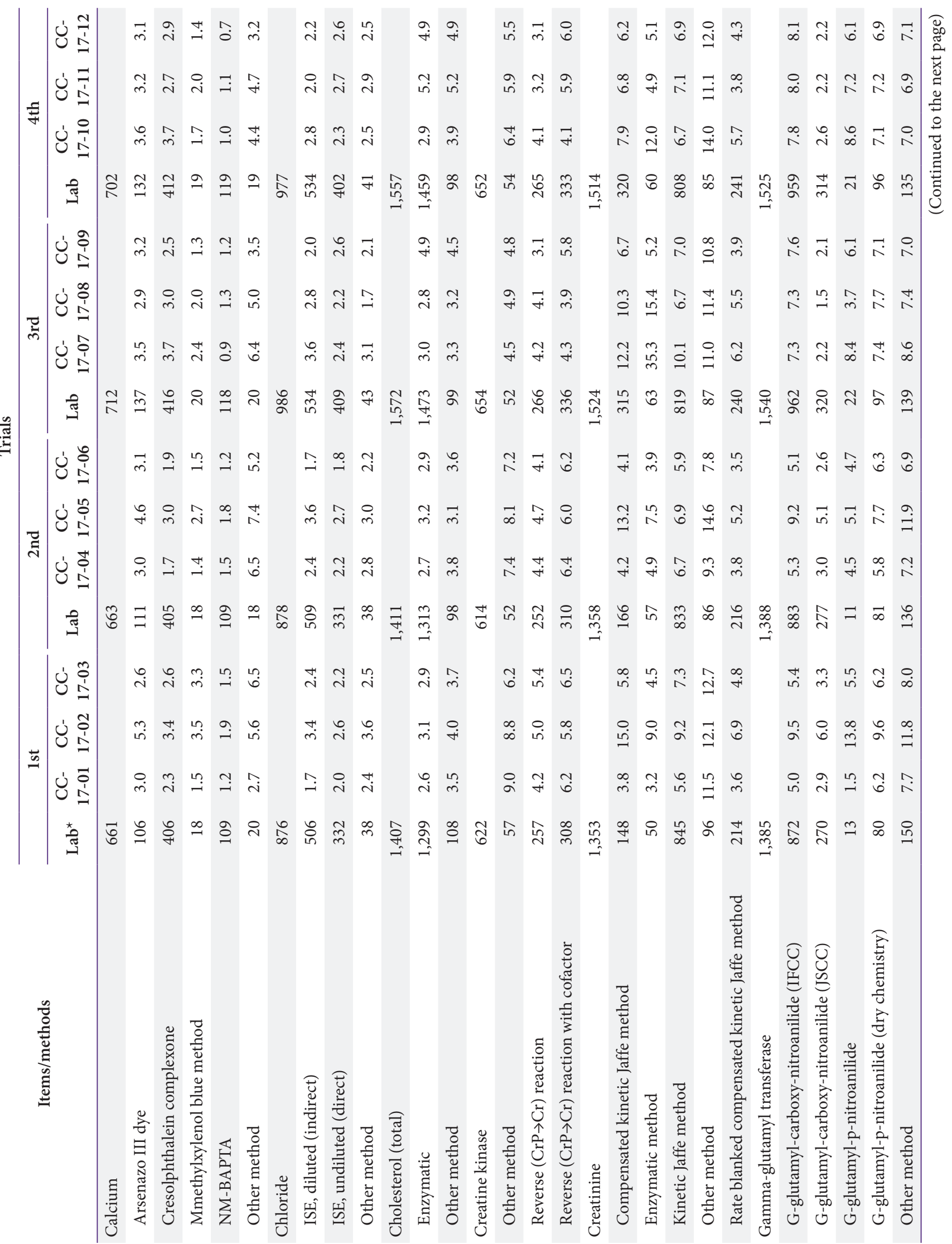




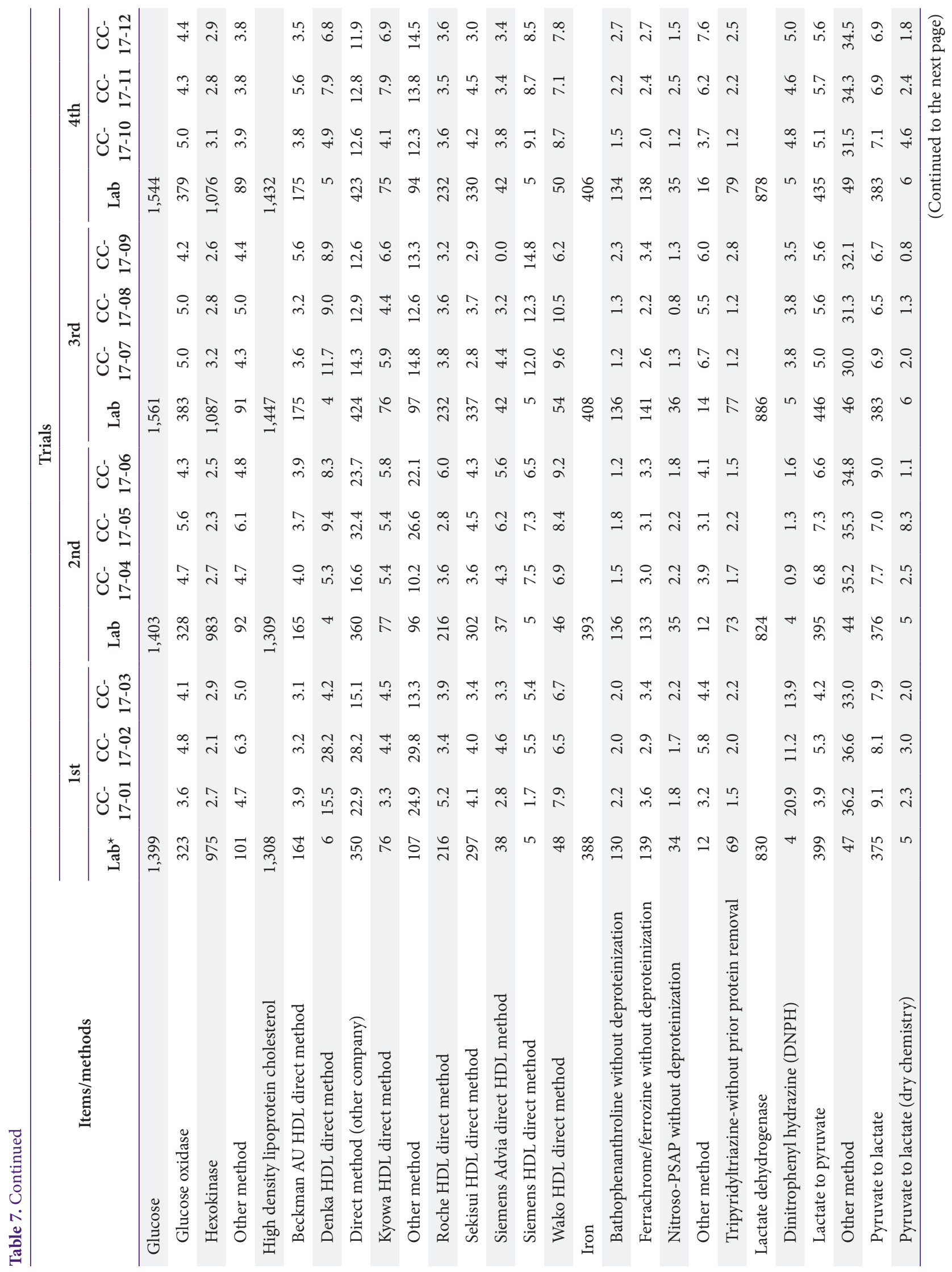




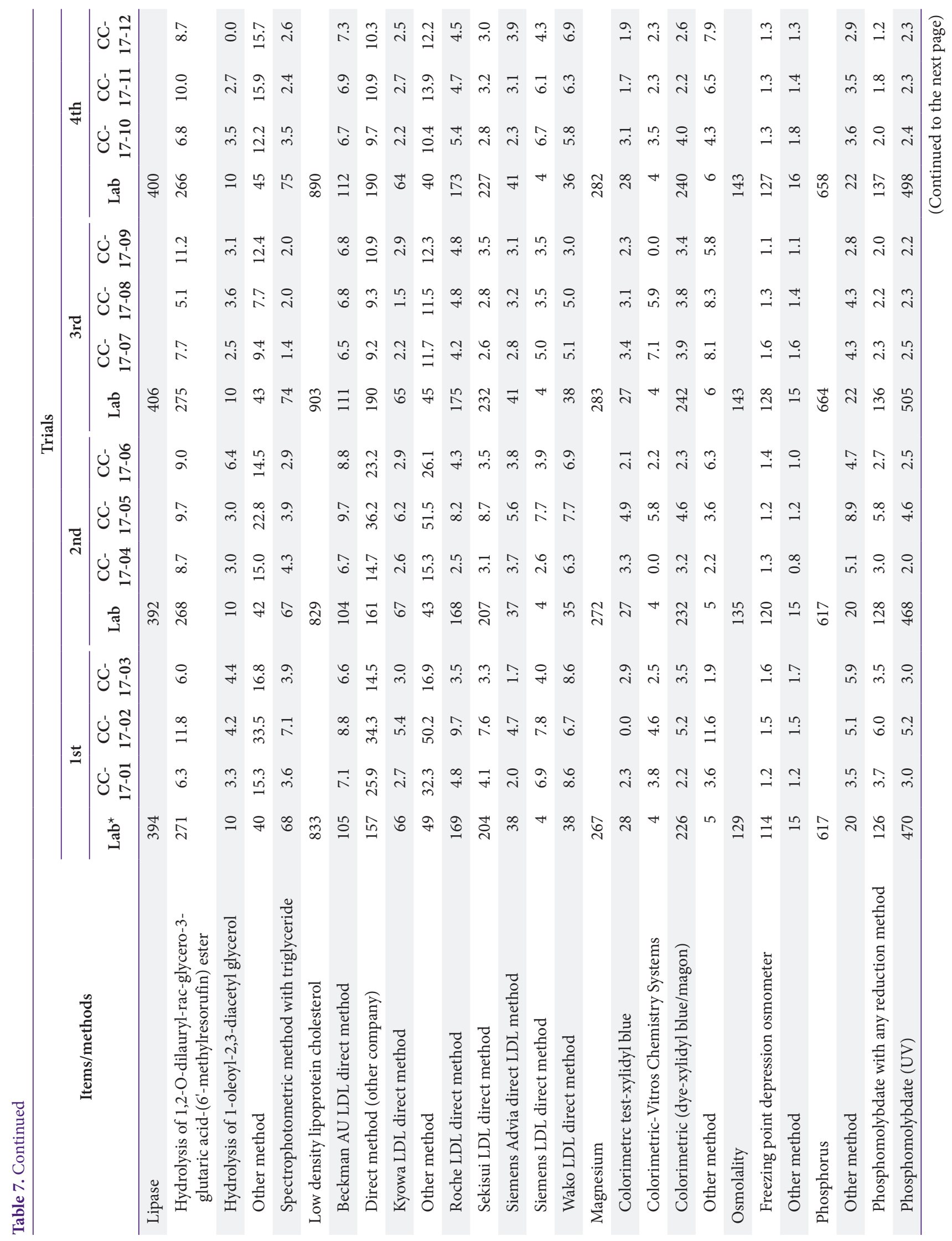


Yong-Wha Lee • External Quality Assessment for General Chemistry

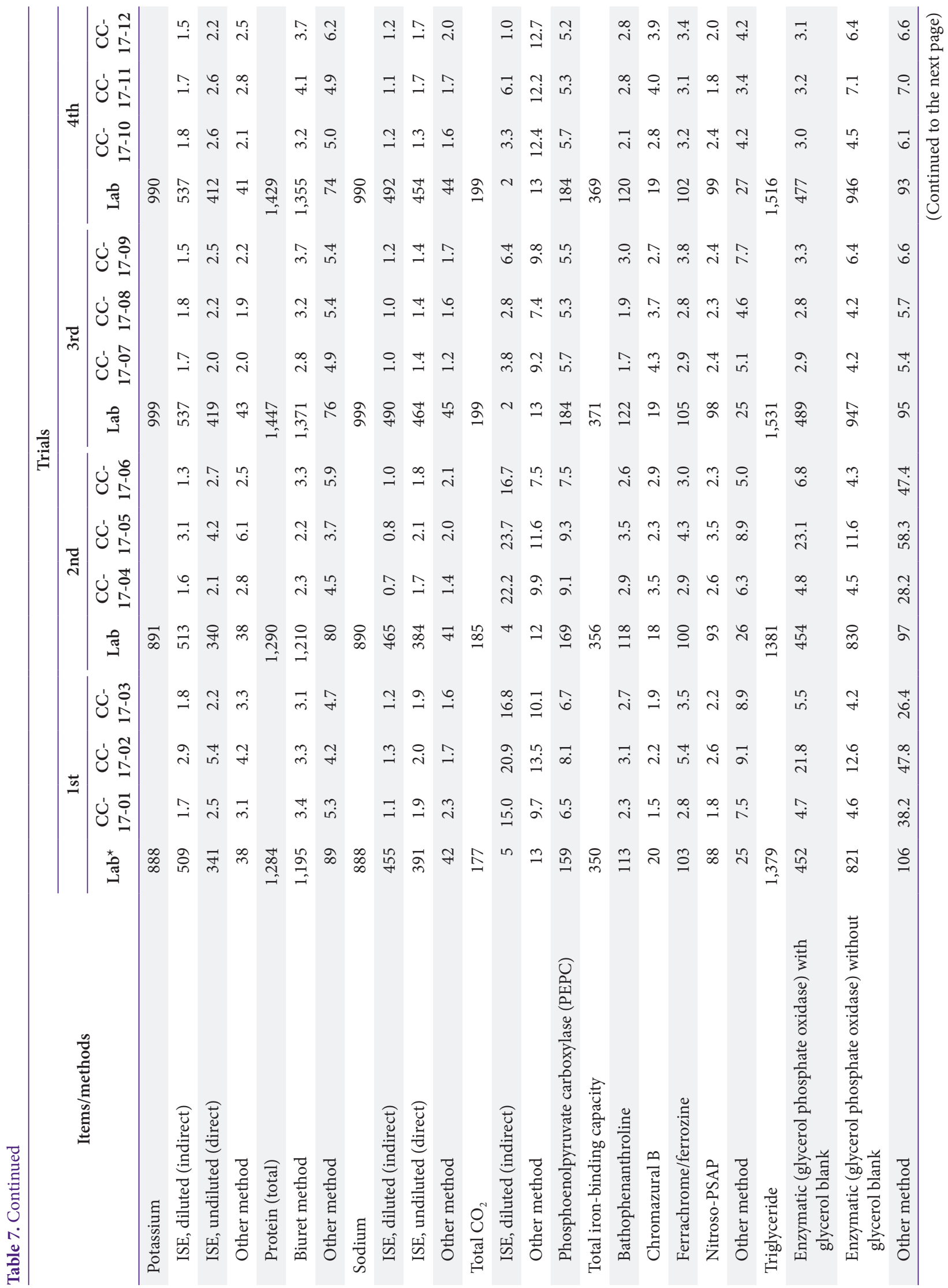




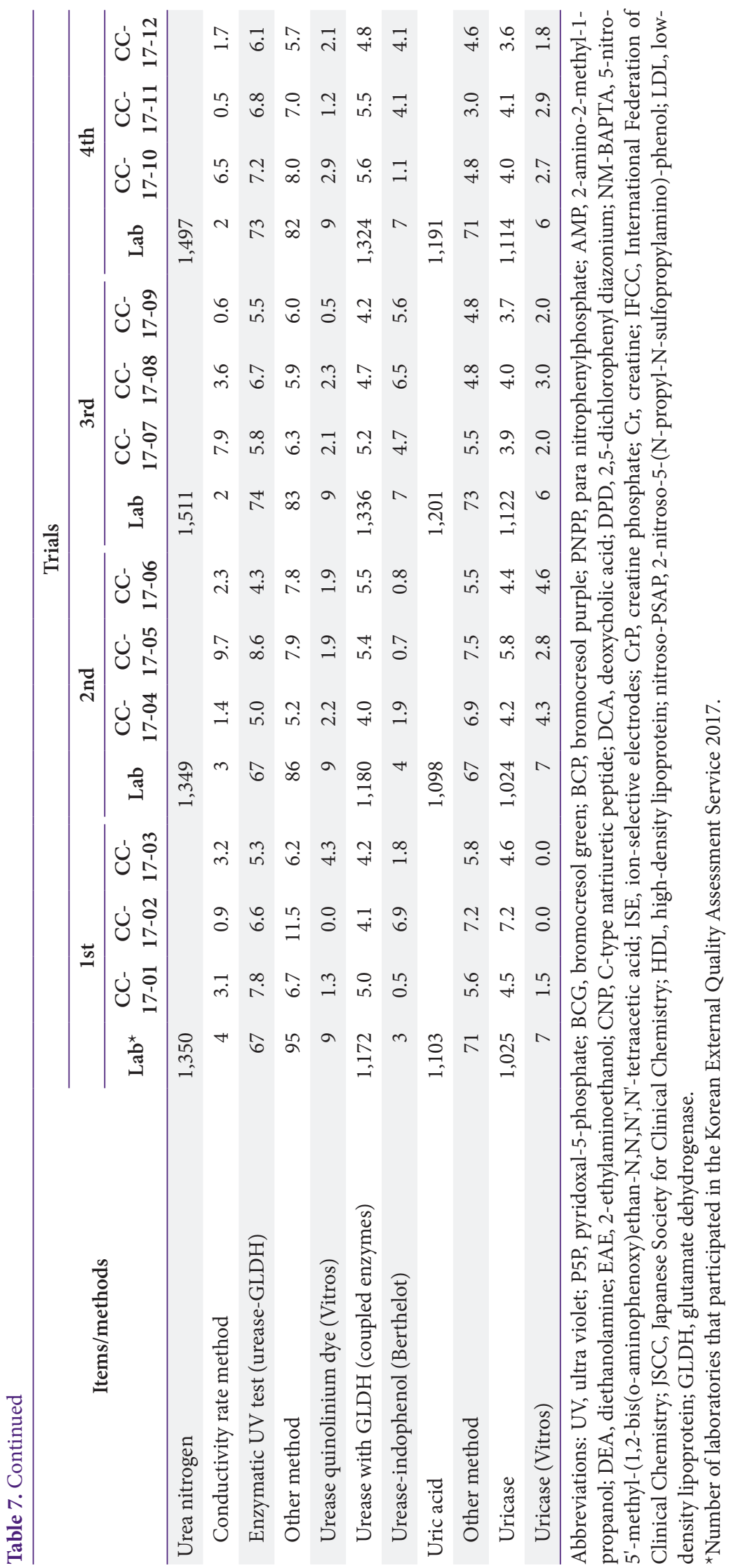




\section{Journal of LABORATORY MEDICINE and QUALITY ASSURANCE}

\section{Yong-Wha Lee • External Quality Assessment for General Chemistry}

Table 8. Distribution of analytical methods (principle) participated and coefficients of variation (\%) according to urine chemistry principles in 2017

\begin{tabular}{|c|c|c|c|c|c|c|c|c|}
\hline \multirow{3}{*}{ Items/methods } & \multicolumn{8}{|c|}{ Trials } \\
\hline & \multicolumn{4}{|c|}{1 st } & \multicolumn{4}{|c|}{ 2nd } \\
\hline & $\mathrm{Lab}^{*}$ & $\begin{array}{c}\text { CUC-17- } \\
01\end{array}$ & $\begin{array}{l}\text { CUC-17- } \\
02\end{array}$ & $\begin{array}{c}\text { CUC-17- } \\
03\end{array}$ & Lab & $\begin{array}{l}\text { CUC-17- } \\
04\end{array}$ & $\begin{array}{l}\text { CUC-17- } \\
05\end{array}$ & $\begin{array}{l}\text { CUC-17- } \\
06\end{array}$ \\
\hline Albumin & 123 & & & & 134 & & & \\
\hline Immunoturbidimetry & 114 & 34.1 & 36.6 & 22.7 & 123 & 43.8 & 21.9 & 22.1 \\
\hline Other method & 6 & 50.3 & 54.7 & 27.9 & 7 & 53.0 & 35.4 & 37.8 \\
\hline Calcium & 117 & & & & 130 & & & \\
\hline Arsenazo III dye & 12 & 3.7 & 3.7 & 2.9 & 16 & 4.4 & 3.2 & 2.7 \\
\hline Cresolphthalein complexone & 66 & 3.5 & 3.3 & 2.5 & 74 & 2.1 & 2.4 & 2.3 \\
\hline NM-BAPTA & 34 & 2.2 & 3.2 & 1.9 & 36 & 2.5 & 2.1 & 1.6 \\
\hline Chloride & 131 & & & & 147 & & & \\
\hline ISE, diluted (indirect) & 128 & 8.1 & 9.4 & 3.2 & 144 & 8.7 & 2.7 & 2.8 \\
\hline Other method & 3 & 6.5 & 7.5 & 1.2 & 3 & 0.2 & 3.3 & 2.7 \\
\hline Creatinine & 142 & & & & 160 & & & \\
\hline Compensated kinetic Jaffe method & 37 & 2.7 & 3.8 & 3.1 & 41 & 3.7 & 2.8 & 3.7 \\
\hline Enzymatic method & 7 & 3.0 & 2.3 & 4.2 & 9 & 5.1 & 5.5 & 3.9 \\
\hline Kinetic Jaffe method & 38 & 4.7 & 3.4 & 5.0 & 45 & 5.2 & 4.6 & 5.3 \\
\hline $\begin{array}{l}\text { Rate blanked compensated kinetic Jaffe } \\
\text { method }\end{array}$ & 59 & 2.7 & 3.6 & 3.4 & 64 & 2.9 & 3.2 & 2.5 \\
\hline Glucose & 111 & & & & 122 & & & \\
\hline Hexokinase & 109 & 3.1 & 3.4 & 2.4 & 121 & 3.7 & 2.4 & 2.7 \\
\hline Magnesium & 96 & & & & 100 & & & \\
\hline Colorimetrc test-xylidyl blue & 9 & 8.1 & 7.4 & 7.1 & 9 & 3.6 & 8.4 & 11.5 \\
\hline Colorimetric (dye-xylidyl blue/magon) & 86 & 3.4 & 4.2 & 6.2 & 89 & 3.2 & 5.1 & 4.7 \\
\hline Phosphorus & 113 & & & & 121 & & & \\
\hline Phosphomolybdate (UV) & 112 & 3.0 & 3.1 & 3.8 & 119 & 2.8 & 2.7 & 2.9 \\
\hline Potassium & 132 & & & & 148 & & & \\
\hline ISE, diluted (indirect) & 129 & 2.3 & 2.7 & 4.2 & 145 & 2.4 & 4.0 & 4.3 \\
\hline Protein & 129 & & & & 143 & & & \\
\hline Biuret method & 6 & 12.1 & 10.4 & 9.2 & 6 & 8.9 & 6.7 & 4.7 \\
\hline Dye binding using pyrogallol red & 71 & 16.7 & 16.5 & 10.6 & 80 & 15.1 & 9.8 & 10.9 \\
\hline Turbidimetry using benzethonium chloride & 50 & 5.7 & 6.9 & 5.0 & 55 & 5.6 & 4.0 & 4.0 \\
\hline Sodium & 132 & & & & 149 & & & \\
\hline ISE, diluted (indirect) & 129 & 2.5 & 2.5 & 1.2 & 146 & 2.4 & 1.2 & 1.2 \\
\hline Urea nitrogen & 121 & & & & 135 & & & \\
\hline Enzymatic UV test (urease-GLDH) & 7 & 2.0 & 2.5 & 8.0 & 10 & 5.8 & 4.3 & 3.8 \\
\hline Urease with GLDH (coupled enzymes) & 114 & 3.4 & 3.2 & 3.3 & 125 & 3.4 & 3.3 & 3.3 \\
\hline Uric acid & 116 & & & & 126 & & & \\
\hline Uricase & 114 & 4.8 & 5.6 & 4.3 & 125 & 4.6 & 3.7 & 3.6 \\
\hline
\end{tabular}

Abbreviations: NM-BAPTA, 5-nitro-5'-methyl-(1,2-bis(o-aminophenoxy)ethan-N,N,N',N'-tetraacetic acid; ISE, ion-selective electrodes; UV, ultra violet; GLDH, glutamate dehydrogenase.

${ }^{*}$ Number of laboratories that participated in the Korean External Quality Assessment Service 2017. 


\section{Journal of LABORATORY MEDICINE and QUALITY ASSURANCE}

Yong-Wha Lee • External Quality Assessment for General Chemistry

관이 가장 많았고 1 회차에 비해 2회차의 참가기관 수가 많았 다(Table 4).

일반화학검사 프로그램에서 변이계수는 각 검사항목별 회차 별로 상대적으로 정도관리물질의 농도가 낮고 참여기관의 수 가 적을수록 높은 경향을 보였다(Table 5). 대부분 $10 \%$ 이내 의 변이계수를 보였지만 ALP, 아밀라아제, 젖산탈수소효소 (lactate dehydrogenase, $\mathrm{LD}$ ), 직접빌리루빈, $\mathrm{HDL}-\mathrm{C}$, 저밀 도지단백콜레스테롤(low-density lipoprotein cholesterol)과 중성지방 등의 일부 방법에서 $10 \%$ 이상의 높은 변이계수를 보였다. 물론 동일한 검사법을 사용하는 그룹 내에서는 비교적 작은 변이계수를 보였으나 $\mathrm{ALP}$ 와 $\mathrm{LD}$ 는 검사법 간에 결과의 차이가 유의하게 커서 변이계수도 상대적으로 매우 큰 것으로 관찰되었다(Table 5).

요화학검사 프로그램에서 각 검사항목별 변이계수는 대부분 $10 \%$ 이내의 값을 보였으나 알부민과 단백은 상대적으로 높은 변이계수를 보였다(Table 6). 변이계수는 각 각 기관의 상대 적 위치를 나타내는 SDI와도 관련되므로 변이계수가 큰 경우 $\mathrm{SDI}$ 는 상대적으로 작아질 수 있으므로 결과해석 시 고려되어 야 한다.

일반화학검사항목에 있어서 측정법의 분포는 전체적으 로 전년도와 큰 차이는 없었고, 한 가지 검사방법이 전체 의 $80 \%$ 를 넘는 검사는 알부민의 dye binding bromocresol green법, ALT와 AST의 ultra violet (UV) without pyridoxal-5-phosphate법, BUN의 urease with glutamate dehydrogenase법, 총 콜레스테롤의 효소측정법, 나트륨, 칼륨 과 염소 등의 전해질의 ion selective electrode법, 마그네슘의 비색법(dye-xylidyl blue/magon), 총 단백의 biuret법과 요산 의 uricase법이었다. 2017년도에 추가로 신설된 삼투압과 총 이산화탄소검사도 freezing point depression osmometer법과 phosphoenolpyruvate carboxylase법이 측정법의 대부분을 차지하였다(Table 7).
요화학검사항목 중 알부민, 포도당, 인(phosphorus)과 단 백은 측정법의 분포가 일반화학검사와 차이가 있었다. 알 부민의 측정법으로는 immunoturbidimetry법이 주로 이 용되었고 단백의 측정법으로 dye binding using pyrogallol red법과 turbidimetry using benzethonium chloride법 이 이용되었다. 포도당과 인검사에는 각각 hexokinase법과 phosphomolybdate, UV법이 이용되었다(Table 8).

2017년 일반화학검사 프로그램과 요화학검사 프로그램의 신빙도조사 결과에 대해 보다 자세한 통계분석 결과는 대한임 상검사정도관리협회 신빙도조사사업 홈페이지(http://eqas. keqas.org)에서 조회가 가능하다. 각 기관의 신빙도조사 결과 에 대한 해석과 검사법 선택 시 본 통계분석 자료가 유용할 것 으로 생각된다.

\section{REFERENCES}

1. Lee YW, Jeon BR, Kim JG, Jun SH, Yun YM, Chun S, et al. Annual report on the external quality assessment scheme for routine clinical chemistry in Korea (2016). J Lab Med Qual Assur 2017;39:61-75.

2. Jun SH, Song J, Song WH; Clinical Chemistry Subcommittee, Korean Association of External Quality Assessment Service. Annual report on the external quality assessment scheme for clinical chemistry in Korea (2015). J Lab Med Qual Assur 2016;38:111-9.

3. Jun SH, Song J; Clinical Chemistry Subcommittee, The Korean Association of External Quality Assessment Service. Annual report on the external quality assessment scheme for clinical chemistry in Korea (2014). J Lab Med Qual Assur 2015;37:115-23. 
Journal of LABORATORY MEDICINE and QUALITY ASSURANCE

Yong-Wha Lee • External Quality Assessment for General Chemistry

일반화학 프로그램 신빙도조사 결과보고(2017)

이용화

순천향대학교 의과대학 순천향대학교부천병원 진단검사의학과

2017년 대한임상검사정도관리협회 신빙도조사사업에서 임상화학분야에는 요화학검사 프로그램 이 추가되어 총 24개의 프로그램으로 구성되었다. 일반화학검사 프로그램은 삼투압(osmolality), 총 이산화탄소(total $\mathrm{CO}_{2}$ )와 추정 사구체여과율검사가 추가된 총 32개의 검사항목으로 구성되었고, 요 화학검사 프로그램은 알부민검사 등 총 12 개의 검사항목으로 구성되었다. 각 기관에서 입력된 검 사항목에 대한 정보와 결과를 기반으로 검사방법, 기기, 시약에 따른 통계분석 자료가 보고되도록 하였다. 제시된 통계에는 각 그룹별 참여기관 수, 평균, 표준편차, 변이계수, 중앙값, 최소값과 최

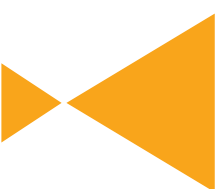

Journal of

LABORATORY MEDICINE and

QUALITY ASSURANCE 대값이 포함되도록 하였고 개별보고서는 각 검사항목별로 통계치를 보여주는 표, 히스토그램, 레 비-제닝스 차트와 표준편차지수로 구성되도록 하였다. 1,000 개 이상의 기관이 참여하는 검사항목 은 알부민 등 총 14 개의 검사항목에 대해서 1,000 개 이상의 기관이 참가하고 있고 참가기관 수가 지속적으로 증가하는 추세이다. 변이계수는 각 검사항목별 회차별로 정도관리물질의 농도가 낮을 수록 높은 경향을 보였으나 대부분 $10 \%$ 이내의 변이계수를 보였다. 알칼리인산분해효소(alkaline phosphatase)와 젖산탈수소효소(lactate dehydrogenase)는 검사법 간에 결과의 차이가 유의하게 커 서 변이계수도 상대적으로 매우 큰 것으로 관찰되었다. 일반화학검사항목에 있어서 측정법의 분포 는 전체적으로 전년도와 큰 차이는 없었고, 요화학검사항목 중 알부민, 포도당, 인(phosphorus), 단 백은 측정법의 분포가 일반화학검사와 차이가 있었다.

(J Lab Med Qual Assur 2018;40:113-127)

교신저자: 이용화

우)14584 경기도 부천시 원미구 조마루로 170 , 순천향대학교 의과대학 순천향대학교부천병원 진단검사의학과 Tel: 032)621-5943, Fax: 032)621-5944, E-mail: lywmd@schmc.ac.kr 